Mohammad Hossein Haddadi ${ }^{1}$, Maqsadollah Esmaeilov², Rajab Choukan ${ }^{3}$, Valiollah Rameeh ${ }^{4}$

${ }^{1,4}$ Agricultural and Natural Resources Research Center of Mazandran, Sari, Iran; ${ }^{2}$ Tajik Agricultural University;

${ }^{3}$ Seed and Plant Improvement Institute, Karaj, Iran; vrameeh@yahoo.com

\title{
GENE ACTION AND COMBING ABILITY OF SOME AGRONOMIC TRAITS IN CORN USING DIALLEL ANALYSIS
}

\begin{abstract}
Combining ability estimates are important genetic attributes to maize breeders in anticipating improvement via hybridization and selection. To determine the combining ability for yield and yield associated traits, 8 diverse corn inbred lines were used in a half diallel mating design. Twenty eight F1 progenies along with their parents were planted in randomized complete block design with four replications in two locations during two years. Combined analysis of variance showed significant mean squares of general combining ability (GCA) and specific combing ability (SCA) for Days to silking emergence (DS), plant height (PH), 1000-kernel weight (KW), number of kernels in ear row (KR), number of rows in ear( NR ), ear diameter (ED), cob diameter (CD), kernel yield (KY) indicating that the importance of both additive and non additive genetic effects for these traits. However, high narrow-sense heritability estimates, low degree of dominance and the ratio of estimates of GCA to SCA effects for DS, NR and CD indicated that additive genetic effect was more important for these traits. Most of the crosses with significant SCA effects for KY had at least one parent with significant GCA effects for the same traits. Significant positive correlations were detected between $\mathrm{KY}$ and other yield components including $\mathrm{KW}, \mathrm{KR}, \mathrm{NR}$ and $\mathrm{ED}$, therefore these traits can be used as indirect selection criteria for KY improvement. The crosses MO17 $\times$ Line8, MO17 $\times$ Line 10 and MO17 $\times$ Line 12 , Line $8 \times$ Line 10 and Line $8 \times$ Line 21 with high values of KY were considered as good cross combinations for improving the trait.
\end{abstract}

Key words: combined analysis, correlation, dominance, heritability, maize.

Communicated by Grzegorz Żurek 


\section{INTRODUCTION}

Corn (Zea mays L.) has a notable place among cereals and it is used as human food, animal feeding and industry (Keskin et al., 2005). Advances in corn genomics, breeding and production have important role on the lives of a large proportion of the world's population (Xu and Crouch, 2008). The main principle of corn breeding is to develop new inbred lines and hybrids that will outperform the existing hybrids with respect to a number of characteristics. For attending this purpose, particular attention is paid to grain yield as the most economically important trait in corn (Vasic et al., 2001). Grain yield is a complex quantitative trait which is affected by a number of components, including kernel row number and kernel number per row (Zivanovic et al., 2007; Bovanski et al., 2009).

The identification of parental inbred lines that can be used for improving superior hybrids is the most costly and time consuming phase in corn hybrid development. Per se performance of corn inbred lines does not predict the performance of corn hybrids for grain yields (Hallauer and Miranda, 1988). Single cross hybrid performance or heterosis between parental inbred lines could therefore increase the efficiency of hybrid breeding programs (Betran et al., 2003). The main objective of corn breeding is improving new hybrids with high genetic potential for yield and positive features that exceed the existing commercial hybrids (Secanski et al., 2005). Therefore, combining ability analysis is an important method to realize gene actions and it is frequently used by crop breeders to select parents with a high general combining ability (GCA) and hybrids with high specific combining ability (SCA) effects (Yingzhong, 1999). Variance for GCA is related to additive genetic effects, whereas SCA indicating non-additive genetic effects, arising largely from dominance and epistatic deviations with respect to certain traits. In a classic breeding program, it is necessary to identify superior parents for hybridization and crosses to expand the genetic variability for selection of superior genotypes (Hallauer and Miranda, 1988). Genetic designs including diallel analysis have been extensively used in plant breeding to determine combining abilities of the parental lines in order to recognize superior parents for use in hybrid production (Fry, 2004; Griffing, 1956; Hayman, 1954). Combining ability has been applied by several researchers for corn breeding programs (Beck et al., 1990; Crossa et al., 1990; Vasal et al., 1992; Kang et al., 1995; Kim and Ayala, 1996; Xingming et al., 2001; Betran et al., 2002; Revila et al., 2002; Glover et al., 2005). Fry (2004) reported that heritability of a trait approaches its maximum in successive generations following hybridization. In addition, the existence of additive gene effects for a trait indicates the presence of additive variation, which means that selection could be successful for the trait (Fehr, 1991). Ojo et al. (2007) reported significant positive heterosis for grain yield and yield components including ear length and ear diameter in diallel crosses of seven white corn inbred lines. Additive gene action was also more important than non-additive gene action for grain yield. Ottaviano and Camussi (1981) 
examined several agronomic traits in diallel crosses of 10 inbred lines and their 45 F1 hybrids to study their genetic relationships with grain yield.

Large genotype $\times$ environment interaction effects tend to be viewed as problematic in breeding because the lack of a predictable response delays progress from selection. Most of the literature about corn, suggests that additive effects of genes with partial to complete dominance are more important than dominance effects in determining grain yield (Novoselovic et al., 2004; Lamkey and Lee, 1993). Given the diversity of environments in which corn is cropped in Iran, the hybrid by environment interaction is normally expressive (Aguiar et al., 2003). Therefore it is necessary to identify hybrids that present not only wide adaptation, assessed by the mean yield, but also have high stability, i.e., with homeostasis to adjust to environmental changes. Some studies have already compared stability in different types of hybrids (Cvarkovic et al., 2009). However, there is little information regarding stability of the GCA and SCA effects. Probably single-crosses with higher stability in the GCA and SCA, the hybrid combinations obtained from these parents also present higher homeostasis for environmental variations.

The objectives of the diallel study presented here were to estimate genetic parameters like general and specific combining abilities of eight inbred lines of corn and correlations between grain yield and its components as well as other traits in different environments to recognize and choose the best parents and crosses in breeding programs.

\section{MATERIALS AND METHODS}

Eight inbred lines of maize namely Line 8, Line10, Line 12, Line 21, Line 24, Line 33, Line 36 and MO17 were crossed $8 \times 8$ diallel fashion (excluding reciprocals) to obtain $28 \mathrm{~F}_{1}$ crosses in 2010 . The resulting $28 \mathrm{~F} 1$ progenies along with their parents were evaluated using a randomized complete block design with four replications at two locations; Dashtenaz Agronomy Research Station located in Sari, Iran (53 $11^{\prime}$ E longitude and $36^{\circ} 37^{\prime} \mathrm{N}$ latitude, $10.5 \mathrm{~m}$ above sea level) and Qarakheil Agronomy Research Station located in Qaemshahr, Iran (52 $46^{\prime}$ E longitude and $36^{\circ} 27^{\prime} \mathrm{N}$ latitude, $14.7 \mathrm{~m}$ above sea level) during spring 2011-12. In each location the plots consisted of 3 rows, $5 \mathrm{~m}$ long and $75 \mathrm{~cm}$ apart and intra-row spacing of $20 \mathrm{~cm}$. Crop management practices which included land preparation, crop rotation, fertilizer, and weed control were followed as recommended for each site. All the plant protection measures were adopted to make the crop free from insects. Ten competitive plants from the middle of each row were sampled and the following traits were recorded for each cross at each location during two years: days to silking (DS), plant height $(\mathrm{PH})$ in $\mathrm{cm}$, 1000 -kernel weight $(\mathrm{KW})$ in gram, number of kernels in ear row (KR), 
number of rows in ear (NR), ear diameter (ED) $\mathrm{cm}$, cob diameter (CD) in $\mathrm{cm}$, kernel yield (KY) in ton per hectare.

Data were analysed using the following statistical model:

$$
\begin{gathered}
Y i j k l=\mu+\alpha l+b k l+v i j+(\alpha v) i j l+e i j k l \\
v i j=g i+g j+s i j
\end{gathered}
$$

where Yijkl is observed value from each experimental unit; $\mu$ is a population mean; $\alpha l$ - location effect; $b k l$ block or replication effect within each location; vij $-\mathrm{F}_{1}$ hybrid effect, gi means general combining ability (GCA) for the $i^{\text {th }}$ parent; $g j$ is GCA effect of $j^{\text {th }}$ parent; $s i j$ - specific combining ability (SCA) for the $i j^{\text {th }} \mathrm{F} 1$ hybrid), ( $\left.\alpha v\right) i j l$ - interaction effect between $i j^{\text {th }} \mathrm{F}_{1}$ hybrid and location; eijkl = random residual effect.

The combining ability analysis was performed using mean values of the $F_{1}$ generation along with parents by using Griffing's method 2 . The statistical t-Student test was applied to examine the effects GCA and SCA.

Pearson coefficient of correlation was detected based on means values the traits as:

$$
r=\frac{\text { Covariance }(X Y)}{\sqrt{\operatorname{Variance}(X) \times \operatorname{Variance}(Y)}}
$$

where $\mathrm{X}$ and $\mathrm{Y}$ were considered as different traits under study.

A special SAS software (version 9) tool for diallel analysis developed by Zhang et al. (2005) was used to determine GCA effects, SCA effects, and their interaction effects with locations and also coefficient of correlation.

\section{RESULTS AND DISCUSSION}

\section{Combined diallel analysis of variance}

Results of combined analysis of variance across environments revealed that environment effects were highly significant $(P<0.01)$ for days from emergence to silking (DS), plant height(PH), 1000-kernel weight (KW), number of kernels in ear row (KR), ear diameter (ED), cob diameter (CD), kernel yield (KY) indicating that these traits are influenced by environmental conditions. While, environment effects was not significant $(P>0.05)$ for number of rows in ear (NR), indicating this trait is not influenced by environmental conditions (Table 1). Other researchers have found that environment effects were significant for days from emergence to silking, plant height (Mickelson et al., 2001), number of rows per ear, number of kernels 
per row (Vidal-Martinez et al., 2001) and grain yield (Doerksen et al., 2003; Soengas et al., 2003; Mickelson et al., 2001; Vidal-Martinez et al., 2001). Significant mean squares of general combining ability (GCA) and specific combining ability (SCA) estimates were detected for all the traits indicating the importance of both additive and non additive genetic effects for these traits (Table 1). Similarly, in earlier studies (Beck et al., 1990; Crossa et al., 1990; Vasal et al., 1992; Kang et al., 1995; Kim and Ayala, 1996; Xingming et al., 2001; Bertan et al., 2002; Revilla et al., 2002; Glover et al., 2005) were recorded significant mean square of GCA and SCA effects of yield components in corn.

Combined analysis of variance for different traits in 8 corn inbred lines and their $F_{1}$ diallel crosses across 4 environments ( two years and two locations).

\begin{tabular}{lccccccccc}
\hline \multicolumn{1}{c}{ S.O.V } & DF & DS & PH & KW & KR & NR & ED & CD & KY \\
\hline Env.(E) & 3 & $4820.2^{* *}$ & $36258.79^{* *}$ & $50533.38^{* *}$ & $237.64^{* *}$ & $4.22^{\mathrm{NS}}$ & $2.82^{* *}$ & $0.376^{* *}$ & $150.59^{* * *}$ \\
E (REP) & 12 & $134.98^{* *}$ & $2565.7^{* *}$ & $4648.83^{* *}$ & $39.17^{* *}$ & $12.32^{* *}$ & $0.3^{* *}$ & $0.073^{* *}$ & $17.28^{* *}$ \\
Genotypes(G) & 35 & $116.4^{* *}$ & $7812.0^{* *}$ & $5735.17^{* *}$ & $273.89^{* *}$ & $65.39^{* *}$ & $1.58^{* *}$ & $0.67^{* *}$ & $54.1^{* *}$ \\
E×G & 105 & $8.38^{\mathrm{NS}}$ & $532.8^{\mathrm{NS}}$ & $1479.59^{\mathrm{NS}}$ & $24.04^{* *}$ & $7.18^{* *}$ & $0.87^{* *}$ & $0.044^{*}$ & $3.63^{* *}$ \\
GCA & 7 & $363.97^{* *}$ & $5440.53^{* *}$ & $15087.0^{* *}$ & $227.7^{* *}$ & $208.9^{* *}$ & $3.2^{* *}$ & $2.17^{* *}$ & $50.47^{* *}$ \\
SCA & 28 & $46.14^{* *}$ & $8435.6^{* *}$ & $3983.77^{* *}$ & $290.26^{* *}$ & $28.66^{* *}$ & $1.09^{* *}$ & $0.27^{* *}$ & $56.93^{* *}$ \\
GCA $\times \mathrm{E}$ & 21 & $10.99^{\mathrm{NS}}$ & $904.04^{*}$ & $1406.39^{\mathrm{NS}}$ & $1.45^{\mathrm{NS}}$ & $6.63 * *$ & $0.11^{*}$ & $0.067^{* *}$ & $3.78^{* *}$ \\
$\mathrm{SCA} \times \mathrm{E}$ & 84 & $7.22^{\mathrm{NS}}$ & $469.05^{\mathrm{NS}}$ & $1452.81^{\mathrm{NS}}$ & $1.32^{*}$ & $7.03^{* *}$ & $0.75^{\mathrm{NS}}$ & $0.038^{\mathrm{NS}}$ & $3.47^{* *}$ \\
Error & 420 & 7.67 & 506.97 & 1207.79 & 16.8 & 2.1 & 0.06 & 0.033 & 1.87 \\
GCA/SCA & & $7.89^{* *}$ & $0.645^{\mathrm{NS}}$ & $3.787^{* *}$ & $0.78^{\mathrm{NS}}$ & $7.288^{* *}$ & $2.928^{* *}$ & $8.07^{* *}$ & $0.886^{\mathrm{NS}}$ \\
$\mathrm{h}_{\mathrm{N}}^{2}$ & & 0.607 & 0.1047 & 0.4318 & 0.1266 & 0.5907 & 0.365 & 0.618 & 0.146 \\
$\mathrm{~d} / \mathrm{a}$ & & 1.08 & 4.01 & 1.35 & 3.6 & 1.13 & 1.81 & 1.05 & 3.36 \\
\hline
\end{tabular}

DS: Days to ear silking, PH: plant height, KW: 1000-kernel weight, KR: number of kernels in ear row, NR: number of rows in ear, ED: ear diameter, CD: cob diameter, KY: kernel yield.; Ns, ${ }^{*}$ and **: Non significant , significant at $5 \%$ and $1 \%$ levels , respectively

The narrow-sense heritability estimates were varied from 0.11 to 0.62 for $\mathrm{PH}$ and $\mathrm{CD}$, respectively and the degree of dominance for these traits ranged form 4.01 to 1.05 , respectively. The ratio of the GCA to SCA mean squares of the traits were varied from 0.78 to 7.89 for KR and DS, respectively (Table 1). Due to the moderately high narrow-sense heritability estimates, low degree dominance and significant GCA to SCA mean squares for DS, NR and CD, concluded that the additive genetic effect was more important for these traits. Non significant interaction effects of GCA and environments for DS, KW and KR revealed that the trend of variation of 
GCA effects of parents were similar across the environments including years and locations. Non significant interaction effects of SCA $\times$ environments for most of the traits except KR and KY, indicated similar trend variations of SCA effects for most of the traits except KR and KY.

General combining ability of the parents

Table2

General combining effects of 8 corn lines for grain yield and related traits in two years and two locations using Griffing's method 2

\begin{tabular}{|c|c|c|c|c|c|c|c|c|}
\hline $\begin{array}{l}\text { Traits } \rightarrow \\
\text { Lines } \downarrow\end{array}$ & DS & $\mathrm{PH}$ & $\mathrm{KW}$ & $\mathrm{KR}$ & NR & ED & $\mathrm{CD}$ & $\mathrm{KY}$ \\
\hline MO17 & $3.07 * *$ & $-6.53 * *$ & $21.26^{* *}$ & $1.7 * *$ & $-1.45^{* *}$ & $-0.15 * *$ & $-0.168 * *$ & $0.64 * *$ \\
\hline Line8 & $1.146^{*}$ & $9.54 * *$ & $4.85^{\mathrm{N} \mathrm{S}}$ & $0.42^{\mathrm{NS}}$ & $0.96 * *$ & $0.17 * *$ & $0.092 * *$ & $0.875 * *$ \\
\hline Line10 & $0.19^{\mathrm{NS}}$ & $5.94 * *$ & $-3.37^{\mathrm{N} \mathrm{S}}$ & $2.03 * *$ & $-0.12^{\mathrm{NS}}$ & $-0.09 * *$ & $-0.069 * *$ & $0.207^{\mathrm{N} \mathrm{S}}$ \\
\hline Line12 & $-1.22 * *$ & $-4.55^{*}$ & $3.61^{\mathrm{NS}}$ & $-0.62^{\mathrm{NS}}$ & $0.68 * *$ & $0.2 * *$ & $0.154 * *$ & $0.21^{\mathrm{NS}}$ \\
\hline Line21 & $-0.22^{\mathrm{NS}}$ & $-5.52 * *$ & $-3.89^{\mathrm{N} \mathrm{S}}$ & $-1.07^{*}$ & $0.39 * *$ & $0.061 * *$ & $0.07 * *$ & $-0.45^{* *}$ \\
\hline Line24 & $0.17^{\mathrm{NS}}$ & $2.2^{\mathrm{NS}}$ & $-3.06^{\mathrm{N} \mathrm{S}}$ & $-0.7^{\mathrm{NS}}$ & $0.05^{\mathrm{NS}}$ & $0.06 * *$ & $0.1 * *$ & $-0.189^{\mathrm{N} \mathrm{S}}$ \\
\hline Line 33 & $-1.28 * *$ & $3.63^{\mathrm{NS}}$ & $-7.58 *$ & $-0.62^{N S}$ & $0.52 * *$ & $-0.04^{\mathrm{NS}}$ & $-0.027^{\mathrm{NS}}$ & $-0.443 * *$ \\
\hline Line36 & $-1.85^{* *}$ & $-4.71^{*}$ & $-11.83 * *$ & $-1.14 * *$ & $-1.03 * *$ & $-0.22 * *$ & $-0.15^{* *}$ & $-0.845 * *$ \\
\hline
\end{tabular}

DS: Days to ear silking, PH: plant height, KW: 1000-kernel weight, KR: number of kernels in ear row, NR: number of rows in ear, ED: ear diameter, CD: cob diameter, KY: kernel yield; Ns, ${ }^{*}$ and **: Non significant significant at $5 \%$ and $1 \%$ levels , respectively

The mean of combining ability effects of parents for all the traits across the environments are presented in Table 2 . For improving the early maturity maize genotypes lower values of DS is favorable, therefore Line 12, Line 33 and Line 36 with significant negative GCA effects were considered as good combiners for improving this trait. The parents; Line 33 and Line 36 with mean of 60.06 and 60.94 for DS are more profitable for improving this trait (Table 3). Lower plant height makes more tolerant to lodging, therefore the parents MO17, Line12 and Line 21 with means of $153.91,147.33$ and $160.06 \mathrm{~cm}$ of $\mathrm{PH}$, respectively were suitable parents for this trait. All of these parents had significant negative GCA effects of PH. The mean of KW ranged from 227.86 to $280.14 \mathrm{~g}$ and the parents MO17, Line 12 and Line21 with 261.76, 268.03 and 280.14g mean of KW had high mean values for this trait. The Parent MO17 with significant positive GCA effect for KW was considered to be good combiners for improving this trait. Parents Line10 and MO17 had significant positive GCA effects for KR, hence were good combiners for increasing this trait. The mean value of the parents for KR varied from 26 to 32.5 in Line 24 and Line 10, respectively. Parents Line 8, Line 12, Line 21 and Line 33 had significant positive GCA effects for NR. The high values of this trait were detected for Line 8 and Line 22. Parents Line 8 and Line 12, Line 21 and Line 33 had sig- 
nificant positive GCA effects for ED making them good combiners for improving the trait. In addition, these parents had high mean values for ED (Table 3). The parents L10 and MO17 which had significant negative GCA effects for CD were good combiners for improving the trait. The low means value of this trait were also detected for MO17 and Line 36. Inbred lines Line 8, Line10, Line 12 and Line 21 had high means for KY (Table 3). Inbred lines MO17 and Line 8 with significant positive GCA effects of KY were good combiners for improving seed yield. Ojo et al. (2007) reported significant GCA effects for grain yield and yield components including ear length and ear diameter in diallel crosses of seven white corn inbred lines.

Table 3

Means of parents for different traits in eight corn lines in two years and two locations

\begin{tabular}{ccccccccc}
\hline Parents & DS & $\begin{array}{c}\mathrm{PH} \\
{[\mathrm{cm}]}\end{array}$ & $\begin{array}{c}\text { KW } \\
{[\mathrm{g}]}\end{array}$ & KR & NR & $\begin{array}{c}\text { ED } \\
{[\mathrm{cm}]}\end{array}$ & $\begin{array}{c}\text { CD } \\
{[\mathrm{CM}]}\end{array}$ & $\begin{array}{c}\text { KY } \\
{\left[\mathrm{ton}^{\circ} \mathrm{ha}^{-1}\right]}\end{array}$ \\
\hline MO17 & 70.44 & 153.91 & 261.76 & 26.38 & 12.00 & 3.63 & 2.01 & 3.95 \\
Line8 & 66.00 & 169.49 & 258.51 & 29.50 & 16.06 & 4.31 & 2.48 & 5.63 \\
Line10 & 65.38 & 175.01 & 242.96 & 32.50 & 15.19 & 4.14 & 2.42 & 5.94 \\
Line12 & 63.38 & 147.33 & 268.03 & 26.94 & 15.88 & 4.48 & 2.67 & 5.48 \\
Line21 & 63.19 & 160.06 & 280.14 & 29.44 & 15.06 & 4.33 & 2.64 & 5.43 \\
Line24 & 65.88 & 163.32 & 244.48 & 26.00 & 13.81 & 3.98 & 2.42 & 3.97 \\
Line33 & 60.06 & 186.60 & 258.18 & 30.25 & 15.14 & 4.06 & 2.37 & 5.11 \\
Line36 & 60.94 & 167.16 & 227.86 & 24.38 & 12.94 & 3.54 & 2.06 & 3.23 \\
LSD5\% & 1.912 & 15.56 & 24.04 & 2.838 & 1.087 & 0.169 & 2.43 & 0.96 \\
\hline
\end{tabular}

\section{Specific combining ability of the crosses}

The result of SCA effects of crosses across the four environments for the different traits are presented in Table 4. Non of the crosses had significant SCA effects for DS. This could be due to the relatively high narrow-sense heritability estimates that were observed for the trait, an indication that additive genetic effects were more important. The DS means varied from 57.94 to 65.31 for Line $12 \times$ Line33 and MO17 $\times$ Line8, respectively (Table 5). The crosses with low value for DS had at least one parent with significant negative GCA effect for this trait. The parents can, therefore be used in breeding for early maturity. Out of 28 crosses, 3 crosses had significant SCA effects for PH. The cross MO17 $\times$ L21 with high negative SCA effects for PH was the best cross combination for this trait. Low values for plant height were observed for MO17 $\times$ Line $21(172.98 \mathrm{~cm})$, Line $12 \times$ Line 36 $(187.34 \mathrm{~cm})$ and Line $33 \times$ Line $36(196.35 \mathrm{~cm})$, respectively. 
Specific combining effects of eight corn lines crosses for kernel yield and related traits in two years and two locations using Griffing's method 2

\begin{tabular}{|c|c|c|c|c|c|c|c|c|}
\hline Crosses & DS & $\mathrm{PH}$ & KW & $\mathrm{KR}$ & NR & ED & $\mathrm{CD}$ & KY \\
\hline MO17XLine8 & $-0.69^{\mathrm{NS}}$ & $-2.46^{\mathrm{NS}}$ & $27.57^{* *}$ & $4.16^{* *}$ & $-0.72 * *$ & $0.062^{\mathrm{NS}}$ & $-0.03^{\mathrm{NS}}$ & $2.62 * *$ \\
\hline MO17XLine10 & $0.01^{\mathrm{NS}}$ & $-0.68^{\mathrm{NS}}$ & $27.33^{* *}$ & $2.74 * *$ & $-0.068^{\mathrm{NS}}$ & $0.026^{\mathrm{NS}}$ & $-0.06^{\mathrm{NS}}$ & $0.9^{*}$ \\
\hline MO17XLine12 & $-0.33^{\mathrm{NS}}$ & $21.59^{\mathrm{NS}}$ & $-1.5^{\mathrm{NS}}$ & $5.88 * *$ & $-0.053^{\mathrm{NS}}$ & $0.198 * *$ & $0.072^{\mathrm{NS}}$ & $2.04 * *$ \\
\hline MO17XLine21 & $-2.2^{\mathrm{NS}}$ & $-18.59^{\mathrm{NS}}$ & $-23.24 * *$ & $-5.6^{* *}$ & $0.81 * *$ & $-0.028^{\mathrm{NS}}$ & $0.058^{\mathrm{NS}}$ & $-1.79 * *$ \\
\hline MO17XLine24 & $-0.59^{\mathrm{NS}}$ & $8.83^{\mathrm{NS}}$ & $6.39^{\mathrm{NS}}$ & $2.65^{* *}$ & $0.07^{\mathrm{NS}}$ & $0.108^{\mathrm{NS}}$ & $0.06^{\mathrm{NS}}$ & $0.55^{\mathrm{NS}}$ \\
\hline MO17XLine33 & $1.11^{\mathrm{NS}}$ & $7.3^{\mathrm{NS}}$ & $4.52^{\mathrm{NS}}$ & $1.57^{\mathrm{NS}}$ & $-0.21^{\mathrm{NS}}$ & $0.045^{\mathrm{NS}}$ & $0.081 *$ & $-0.14^{\mathrm{NS}}$ \\
\hline MO17XLine36 & $0.18^{\mathrm{NS}}$ & $20.66^{\mathrm{NS}}$ & $7.96^{\mathrm{NS}}$ & $0.35^{\mathrm{NS}}$ & $1.15^{* *}$ & $0.146^{*}$ & $0.004^{\mathrm{NS}}$ & $0.997^{* *}$ \\
\hline Line $8 X$ Line 10 & $1.12^{\mathrm{NS}}$ & $24.18 * *$ & $-1.72^{\mathrm{NS}}$ & $0.89^{\mathrm{NS}}$ & $0.51^{*}$ & $0.158^{*}$ & $0.062^{\mathrm{NS}}$ & $0.73^{\mathrm{NS}}$ \\
\hline Line $8 X$ Line 12 & $0.28^{\mathrm{NS}}$ & $2.09^{\mathrm{NS}}$ & $10.4^{\mathrm{NS}}$ & $-0.71^{\mathrm{NS}}$ & $0.53^{*}$ & $0.107^{\mathrm{NS}}$ & $0.129 * *$ & $-0.14^{\mathrm{NS}}$ \\
\hline Line $8 X$ Line 21 & $0.41^{\mathrm{NS}}$ & $11.58^{\mathrm{NS}}$ & $-3.43^{\mathrm{NS}}$ & $1.74^{\mathrm{NS}}$ & $-0.31^{\mathrm{NS}}$ & $0.003^{\mathrm{NS}}$ & $-0.059^{\mathrm{NS}}$ & $0.8^{*}$ \\
\hline Line $8 X$ Line 24 & $-1.36^{\mathrm{NS}}$ & $1.00^{\mathrm{NS}}$ & $-5.75^{\mathrm{NS}}$ & $-0.38^{\mathrm{NS}}$ & $0.28^{\mathrm{NS}}$ & $0.025^{\mathrm{NS}}$ & $0.013^{\mathrm{NS}}$ & $0.15^{\mathrm{NS}}$ \\
\hline Line $8 X$ Line 33 & $-0.65^{\mathrm{NS}}$ & $6.74^{\mathrm{NS}}$ & $-14.9^{\mathrm{NS}}$ & $-0.08^{\mathrm{NS}}$ & $1.06 * *$ & $0.09^{\mathrm{NS}}$ & $0.023^{\mathrm{NS}}$ & $-0.22^{\mathrm{NS}}$ \\
\hline Line $8 X$ Line 36 & $-1.02^{\mathrm{NS}}$ & $10.08^{\mathrm{NS}}$ & $7.31^{\mathrm{NS}}$ & $0.44^{\mathrm{NS}}$ & $0.42^{\mathrm{NS}}$ & $0.07^{\mathrm{NS}}$ & $0.11^{* *}$ & $0.011^{\mathrm{NS}}$ \\
\hline Line $10 \mathrm{X}$ Line 12 & $-1.76^{\mathrm{NS}}$ & $-0.238^{\mathrm{NS}}$ & $-6.4^{\mathrm{NS}}$ & $1.06^{\mathrm{NS}}$ & $-0.07^{\mathrm{NS}}$ & $-0.122 *$ & $0.002^{\mathrm{NS}}$ & $0.24^{\mathrm{NS}}$ \\
\hline Line $10 X$ Line 21 & $-1.076^{\mathrm{NS}}$ & $2.81^{\mathrm{NS}}$ & $-0.1^{\mathrm{NS}}$ & $0.76^{\mathrm{NS}}$ & $-0.1^{\mathrm{NS}}$ & $-0.065^{\mathrm{NS}}$ & $-0.104^{* *}$ & $0.16^{\mathrm{NS}}$ \\
\hline Line $10 X$ Line 24 & $-0.53^{\mathrm{NS}}$ & $8.07^{\mathrm{NS}}$ & $4.97^{\mathrm{NS}}$ & $0.57^{\mathrm{NS}}$ & $-0.57^{\mathrm{NS}}$ & $0.024^{\mathrm{NS}}$ & -0.055 & $-0.06^{\mathrm{NS}}$ \\
\hline Line $10 X$ Line 33 & $-0.139^{\mathrm{NS}}$ & $4.43^{\mathrm{NS}}$ & $-0.119^{\mathrm{NS}}$ & $-0.38^{\mathrm{NS}}$ & $0.77 * *$ & $0.14^{*}$ & $0.14 * *$ & $0.35^{\mathrm{NS}}$ \\
\hline Line $10 X$ Line 36 & $-0.818^{\mathrm{NS}}$ & $1.9^{\mathrm{NS}}$ & $-5.41^{\mathrm{NS}}$ & $0.64^{\mathrm{NS}}$ & $0.003^{\mathrm{NS}}$ & $0.011^{\mathrm{NS}}$ & $-0.004^{\mathrm{NS}}$ & $0.0002^{\mathrm{NS}}$ \\
\hline Line $12 X$ Line 21 & $0.96^{\mathrm{NS}}$ & $12.6^{*}$ & $0.444^{\mathrm{NS}}$ & $1.22^{\mathrm{NS}}$ & $0.35^{\mathrm{NS}}$ & $0.112^{\mathrm{NS}}$ & $0.064^{\mathrm{NS}}$ & $0.418^{\mathrm{NS}}$ \\
\hline Line $12 X$ Line 24 & $-1.12^{\mathrm{NS}}$ & $9.62^{\mathrm{NS}}$ & $2.7^{\mathrm{NS}}$ & $0.16^{\mathrm{NS}}$ & $1.07 * *$ & $0.157^{*}$ & $0.05^{\mathrm{NS}}$ & $0.202^{\mathrm{NS}}$ \\
\hline Line $12 X$ Line 33 & $-1.35^{\mathrm{NS}}$ & $8.51^{\mathrm{NS}}$ & $10.53^{\mathrm{NS}}$ & $-0.86^{\mathrm{NS}}$ & $0.35^{\mathrm{NS}}$ & $0.121 *$ & $-0.02^{\mathrm{NS}}$ & $0.58^{\mathrm{NS}}$ \\
\hline Line $12 X$ Line 36 & $-0.717^{\mathrm{NS}}$ & $-7.00^{\mathrm{NS}}$ & $-8.71^{\mathrm{NS}}$ & $-0.21^{\mathrm{NS}}$ & $-0.79 * *$ & $-0.178^{* *}$ & $-0.121 * *$ & $-0.55^{\mathrm{NS}}$ \\
\hline Line $21 X$ Line 24 & $0.26^{\mathrm{NS}}$ & $15.12 *$ & $1.47^{\mathrm{NS}}$ & $0.86^{\mathrm{NS}}$ & $0.79 * *$ & $0.126^{*}$ & $0.083^{*}$ & $0.69^{\mathrm{NS}}$ \\
\hline Line $21 \mathrm{X}$ Line 33 & $0.15^{\mathrm{NS}}$ & $6.64^{\mathrm{NS}}$ & $-7.35^{\mathrm{NS}}$ & $2.35^{*}$ & $-0.24^{\mathrm{NS}}$ & $-0.118^{\mathrm{NS}}$ & $-0.194^{* *}$ & $0.39^{\mathrm{NS}}$ \\
\hline Line $21 X$ Line 36 & $-0.34^{\mathrm{NS}}$ & $2.33^{\mathrm{NS}}$ & $12.55^{\mathrm{NS}}$ & $1.8^{*}$ & $0.32^{\mathrm{NS}}$ & $0.24 * *$ & $0.189 * *$ & $0.84^{*}$ \\
\hline Line $24 X$ Line 33 & $-0.12^{\mathrm{NS}}$ & $-3.18^{\mathrm{NS}}$ & $3.56^{\mathrm{NS}}$ & $-0.47^{\mathrm{NS}}$ & $0.41^{\mathrm{NS}}$ & $0.02^{\mathrm{NS}}$ & $0.126^{* *}$ & $0.62^{\mathrm{NS}}$ \\
\hline Line $24 X$ Line 36 & $-0.29^{\mathrm{NS}}$ & $5.24^{\mathrm{NS}}$ & $4.32^{\mathrm{NS}}$ & $3.93 * *$ & $0.14^{\mathrm{NS}}$ & $0.17 * *$ & $0.042^{\mathrm{NS}}$ & $1.35^{* *}$ \\
\hline Line $33 X$ Line 36 & $0.158^{\mathrm{NS}}$ & $-6.18^{\mathrm{NS}}$ & $-1.28^{\mathrm{NS}}$ & $1.1^{\mathrm{NS}}$ & $-0.33^{\mathrm{NS}}$ & $0.05^{\mathrm{NS}}$ & $-0.045^{\mathrm{NS}}$ & $0.28^{\mathrm{NS}}$ \\
\hline
\end{tabular}

DS: Days to ear silking, PH: plant height, KW: 1000-kernel weight, KR: number of kernels in ear row, NR: number of rows in ear, ED: ear diameter, CD: cob diameter, KY: kernel yield.; Ns,* and **: Non significant, significant at $5 \%$ and $1 \%$ levels, respectively 
Table 5-

Means of different traits in diallel crosses of eight corn lines in two years and two locations

\begin{tabular}{|c|c|c|c|c|c|c|c|c|}
\hline Crosses & DS & $\begin{array}{c}\mathrm{PH} \\
{[\mathrm{cm}]}\end{array}$ & $\begin{array}{r}\text { KW } \\
{[\mathrm{g}]}\end{array}$ & $\mathrm{KR}$ & NR & $\begin{array}{c}\text { ED } \\
{[\mathrm{cm}]}\end{array}$ & $\begin{array}{c}\mathrm{CD} \\
{[\mathrm{CM}]}\end{array}$ & $\begin{array}{c}\mathrm{KY} \\
{[\text { ton/ha] }}\end{array}$ \\
\hline MO17X Line 8 & 65.31 & 204.17 & 321.94 & 41.00 & 14.69 & 4.57 & 2.43 & 11.98 \\
\hline MO17X Line 10 & 65.06 & 202.35 & 313.49 & 41.19 & 14.25 & 4.27 & 2.24 & 9.60 \\
\hline MO17X Line 12 & 63.31 & 214.12 & 291.64 & 41.69 & 15.06 & 4.73 & 2.60 & 10.74 \\
\hline MO17X Line 21 & 62.44 & 172.98 & 262.39 & 29.75 & 15.65 & 4.37 & 2.50 & 6.25 \\
\hline MO17X Line 24 & 64.44 & 208.13 & 292.86 & 38.38 & 14.56 & 4.51 & 2.53 & 8.85 \\
\hline MO17X Line 33 & 64.69 & 208.03 & 286.47 & 37.38 & 14.75 & 4.34 & 2.42 & 7.91 \\
\hline MO17X Line 36 & 63.19 & 213.03 & 285.66 & 35.63 & 14.56 & 4.27 & 2.22 & 8.64 \\
\hline Line $8 X$ Line 10 & 64.25 & 243.27 & 268.03 & 38.06 & 17.25 & 4.73 & 2.62 & 9.67 \\
\hline Line $8 X$ Line 12 & 62.00 & 210.69 & 287.13 & 33.81 & 18.06 & 4.96 & 2.91 & 8.80 \\
\hline Line $8 X$ Line 21 & 63.13 & 219.22 & 265.79 & 35.81 & 16.94 & 4.72 & 2.64 & 9.07 \\
\hline Line $8 X$ Line 24 & 61.75 & 216.36 & 264.30 & 34.06 & 17.19 & 4.75 & 2.74 & 8.69 \\
\hline Line $8 X$ Line 33 & 61.00 & 223.53 & 250.61 & 34.44 & 18.44 & 4.71 & 2.63 & 8.07 \\
\hline Line $8 X$ Line 36 & 60.06 & 218.52 & 268.59 & 34.44 & 16.25 & 4.51 & 2.58 & 7.89 \\
\hline Line $10 \mathrm{X}$ Line 12 & 59.00 & 204.76 & 262.11 & 37.19 & 16.38 & 4.47 & 2.43 & 8.50 \\
\hline Line $10 \mathrm{X}$ Line 21 & 60.69 & 206.84 & 260.91 & 36.44 & 16.06 & 4.39 & 2.51 & 7.76 \\
\hline Line $10 \mathrm{X}$ Line 24 & 61.63 & 219.83 & 266.81 & 36.63 & 15.25 & 4.49 & 2.58 & 7.80 \\
\hline Line $10 \mathrm{X}$ Line 33 & 60.56 & 217.61 & 257.19 & 35.75 & 17.06 & 4.50 & 2.31 & 7.96 \\
\hline Line $10 \mathrm{X}$ Line 36 & 59.31 & 206.74 & 247.66 & 36.25 & 14.75 & 4.19 & 2.83 & 7.21 \\
\hline Line $12 \mathrm{X}$ Line 21 & 61.31 & 206.14 & 268.43 & 34.25 & 17.31 & 4.85 & 2.84 & 8.02 \\
\hline Line $12 X$ Line 24 & 59.63 & 210.88 & 271.52 & 33.56 & 17.69 & 4.90 & 2.64 & 8.07 \\
\hline Line $12 \mathrm{X}$ Line 33 & 57.94 & 211.20 & 274.83 & 32.63 & 17.44 & 4.76 & 2.42 & 8.19 \\
\hline Line $12 X$ Line 36 & 58.00 & 187.34 & 251.34 & 32.75 & 14.75 & 4.29 & 2.79 & 6.67 \\
\hline Line $21 \mathrm{X}$ Line 24 & 62.00 & 215.42 & 262.78 & 33.81 & 17.13 & 4.74 & 2.39 & 7.90 \\
\hline Line $21 \mathrm{X}$ Line 33 & 60.44 & 208.36 & 249.44 & 35.38 & 16.56 & 4.39 & 2.65 & 7.34 \\
\hline Line $21 \mathrm{X}$ Line 36 & 59.38 & 195.71 & 265.10 & 34.31 & 15.58 & 4.57 & 2.74 & 7.39 \\
\hline Line $24 \mathrm{X}$ Line 33 & 60.56 & 206.26 & 261.18 & 32.94 & 16.88 & 4.53 & 2.53 & 7.84 \\
\hline Line $24 \mathrm{X}$ Line 36 & 59.81 & 206.34 & 257.70 & 36.81 & 15.06 & 4.51 & 2.31 & 8.17 \\
\hline Line $33 X$ Line 36 & 58.81 & 196.35 & 247.58 & 34.06 & 15.06 & 4.28 & 2.39 & 6.84 \\
\hline LSD $5 \%$ & 1.912 & 15.56 & 24.04 & 2.838 & 1.087 & 0.169 & 2.43 & 0.96 \\
\hline
\end{tabular}


Correlation between the traits in half diallel crosses of eight parents of maize

\begin{tabular}{|c|c|c|c|c|c|c|c|c|}
\hline Traits & DS & $\mathrm{PH}$ & KW & $\mathrm{KR}$ & NR & ED & $\mathrm{CD}$ & KY \\
\hline DS & 1 & & & & & & & \\
\hline $\mathrm{PH}$ & $0.071 \mathrm{~ns}$ & 1 & & & & & & \\
\hline KW & $-0.016 \mathrm{~ns}$ & $0.27 \mathrm{~ns}$ & 1 & & & & & \\
\hline $\mathrm{KR}$ & $-0.049 \mathrm{~ns}$ & $0.80 * *$ & $0.56^{* *}$ & 1 & & & & \\
\hline NR & $-0.21 \mathrm{~ns}$ & $0.59 * *$ & $0.06 \mathrm{~ns}$ & $0.29 \mathrm{~ns}$ & 1 & & & \\
\hline ED & $-0.051 \mathrm{~ns}$ & $0.66^{* *}$ & $0.41 *$ & $0.54 * *$ & $0.86^{* *}$ & 1 & & \\
\hline $\mathrm{CD}$ & $-0.04 \mathrm{~ns}$ & $0.28 \mathrm{~ns}$ & $0.07 \mathrm{~ns}$ & $0.23 \mathrm{~ns}$ & $0.57 * *$ & $0.65 * *$ & 1 & \\
\hline KY & $0.071 \mathrm{~ns}$ & $0.85 * *$ & $0.61 * *$ & $0.91 * *$ & $0.53 * *$ & $0.77 * *$ & $0.35^{*}$ & 1 \\
\hline
\end{tabular}

Significant, positive correlations were determined for KY with KW, NR and ED (Table 6), implying that crosses with high means value of these traits can be used for improving of KY. Among the crosses, only MO17 $\times$ Line 8 and MO17 $\times$ Line 10 had significant positive SCA effect for KW and these crosses had high means for KW. Significant positive correlation were detected between KR and KY. Therefore, the genotypes with high value for KR will have high KY. The crosses MO17 $\times$ Line 8, MO17 $\times$ Line 10, MO17 $\times$ Line 12, MO17 $\times$ Line 24 , Line $21 \times$ Line 26 and Line $24 \times$ Line 36 had significant positive SCA effect for KR were considered suitable cross combinations for KR. All of the crosses with significant positive SCA effect for KR had at least on parent (MO17) with significant positive GCA effect for KR. Out of 28 crosses, 8 crosses had significant positive SCA effect for NR. Significant positive correlation was determined between ED and KY, therefore this trait can also be used as indirect selection criterion for improving KY. Out of 28 crosses, 6crosses had significant SCA effects for ED. The crosses including MO17 $\times$ Line 12 , MO17 $\times$ Line 36 , Line $10 \times$ Line 36 , Line $12 \times$ Line 24 , Line $12 \times$ Line 33, Line $21 \times$ Line 24, L12 $\times$ L36 and Line $24 \times$ Line 36 had significant positive SCA effects and were considered as good cross combinations for improving ED. Low mean value of $\mathrm{CD}$ is favored, therefore the crosses Line $10 \times$ Line21, Line $12 \times$ Line 36 and Line $21 \times$ Line 36 with significant negative SCA effects were preferred for improving this trait. Out of 28 crosses, 7 crosses had significant SCA effects for KY. Most of the crosses with SCA effects for KY had at least one parent with significant GCA effect for this trait. The crosses MO17 $\times$ Line 8, MO17 $\times$ Line 10 and MO17 $\times$ Line 12 , Line 8 $\times$ Line 10 and Line $8 \times$ Line 21 had high KY were considered as good combinations for improving the trait. Significant SCA effects were reported for 
kernel yield and yield components in diallel crosses of corn breeding lines (Revila et al., 2002; Glover et al., 2005; Fan et al., 2007).

\section{CONCLUSION}

High narrow-sense heritability estimates, low degree dominance and significant GCA to SCA mean squares were estimated for DS, NR and CD, implied that the additive genetic effect was more important for these traits. Non significant interaction effects of GCA and environments for DS, KW and KR indicated that the trend of variation of GCA effects of parents were similar across the environments including years and locations. Non significant interaction effects of SCA $\times$ environments for most of the traits except KR and KY, indicated similar trend variations of SCA effects for most of the traits except KR and KY. Significant, positive correlations were determined for $\mathrm{KY}$ with $\mathrm{KW}$, NR and $\mathrm{ED}$, implying that crosses with high means value of these traits can be used for improving of KY. Most of the crosses with high values of KY had at least one parent with significant positive GCA effect for this trait.

\section{ACKNOWLEDGEMENTS}

The authors wish to thank Agricultural and Natural Resources Research Center of Mazandaran and Seed and Plant Improvement Institute (SPII) for providing genetic materials and facility for conducting experiment.

\section{REFERENCES}

Aguiar AM, CarliniI-Garcia LA, Silva AR, Santos MF, Garcia AAF, Souza CL (2003) Combining ability of inbred lines of maize and stability of their respective singlecrosses; Scientia Agricola, v.60, p.83-89, 2003.

Beck DL, Vassal SK, Crossa J (1990) Heterosis and combining ability of CIMMYT' s tropical early and intermediate maturity maize germplasm. Maydica, 35, 279-285.

Betran FJ, Isakeit T, Odvody G (2002) Aflatoxin accumulation of white and yellow maize inbreds in diallel crosses. Crop Sci., 42, 1894-1901.

Betran FJ, Ribaut JM, Beck D, Gonzalez deLeon D (2003) Genetic diversity, specific combining ability, and heterosis in tropical maize under stress and non-stress environments. Crop Sci. 43: 797-806.

Bovanski J, Sreckov Z, Nastastic A (2009) Genetic and phenotypic relationship between grain yield and components of grain yield of maize (Zea mays L.). Genetika, 41(2), 145-154.

Crossa J, Vasil SK, Beck DL (1990) Combining ability study in diallel crosses of CIMMYT's tropical late yellow maize germplasm. Maydica, 35, 273-278.

Cvarkovic R, Brankovic G, Calic I, Delic N, Zivanovic T, Surlanmomirovic G (2009) Stability of yield and yield components in maize hybrids. Genetika, 41 (2), 215-224.

Doerksen TK, Kannenberg LW, Lee EA (2003). Effect of recurrent selection on combining ability in maize breeding populations. Crop

Sci., 43: 1652-1658.

Fan XM, Chen HM, Tan J, Xu CX, Zhang YD, Luo LM, Huang YX, Kang MS (2008) Combining abilities for yield and yield components in maize. Mayd i ca $53: 39-46$. 
Fehr WR (1991) Principles of cultivar development. Theory and technique. MacMillan Publishing Co., 1: 536.

Fry J D( 2004) Estimation of genetic variances and covariances by restricted maximum likelihood usingPROC MIXED. Pp. 7-39. In A. R. Saxton (ed.). Genetic analysis of complex traits using SAS. Books by Users Press, SAS Inst., Cary, NC.

Glover M, Willmot D, Darrah L, Hibbard B, Zhu $\times(2005)$ Diallel analysis of agronomic traits using Chines and U.S. maize germplasm. Crop Sci., 45(3): 1096-1102.

Griffing B (1956) Concept of general and specific combining ability in relation to diallel crossing system. Aust. J. Biol. Sci., 9: 463-493.

Hallauer AR, Miranda JB (1988) Quantitative genetics in maize breeding. 2nd ed. Iowa State University Press. Ames, IA.

Hayman BI (1954) The analysis of variance of diallel tables. Biometrics, 10: 235-244.

Kang MS, Zhang Y, Magri R (1995). Combining ability for weevil preference of maize grain. Crop Sci., 35, 1556-1559.

Keskin B, Yilmaz IH, Arvas O (2005) Determination of some yield characters of grain corn in eastern Anatolia region of Turkey. J. Agro., 4(1): 14-17.

Kim SK, Ayala SO (1996) Combining abilitiy of tropical maize germplasm in West Africa II.Tropical vs Temperate $\times$ Tropical origins, Maydica, 41, 135-141.

Lamkey KR, Lee M (1993) Quantitative genetics, molecular markers and plant improvement. In Imrie BC, Hacker JB (ed.) Focused plant improvement: Towards responsible and sustainable agriculture. Proc 10th Australian Plant Breeding Conf, Gold Coast, Organising committee, Australian Convention and Travel Service: Canberra, p. 104-115.

Mickelson HR, Cordova H, Pixley KV, Bjarnason MS (2001). Heterotic relationships among nine temperate and subtropical maize populations. Crop Sci., 41: 1012-1020.

Novoselovic D, Baric M, Drezner G, Gunjaca J, Lalic A (2004) Quantitative inheritance of some wheat plant traits. Gen. Mol. Bio., 27(1): 92-98.

Ojo GOS, Adedzwa DK, Bello LL (2007) Combining ability estimates and heterosis for grain yield and yield components in maize (Zea mays L.). J. Sustain. Develop. Agri. Env., 3: 49-57.

Ottaviano E, Camussi A (1981) Phenotypic and genetic relationships between yield components in maize. Euphytica, 30(3): 601-609

Revila P, Malvar RA, Cartea ME, Songas P, Ordas A (2002) Heterotic relationships among European maize inbreds. Euphytica. 126, 259-264.

Secanski M, Zivanovic T, Todorovic G (2005) Components of genetic variability and heritability of the number of rows per ear in silage maize. Biotechnology in Animal Husbandry, 21 (1-2), 109-121.

Soengas P, Ordás B, Malvar RA, Revilla P, Ordás A (2003). Heterotic patterns among flint maize populations. Crop Sci., 43: 844-849.

Vasal SK, Srinivasan G, Pandey S, Gonzalez CF, Crossa J, Beck DL (1993) Heterosis and combining ability of CIMMYT's quality protein maize germplasm: I. Lowland tropical. Crop Sci., 33(1): 46-51.

Vasic N, Ivanovic M, Peternelli L, Jockovic D, Stojakovic M, Bocanski J (2001) Genetic relationships between grain yield and yield components in a synthetic population and their implications in selection. Acta Agronomica Hungarica, 49 (4), 337-342.

Vidal-Martinez VA, Clegg M, Johnson B, Valdivia-Bernal R (2001). Phenotypic and genotypic relationships between pollen and grain yield components in maize. Agrociencia, 35: 503-511.

Xingming F, Jing T, Bihua H, Feng L (2001) Analyses of combining ability and heterotic groups of yellow grain quality protein maize inbreds. 7th Eastern and Southern Africa Regional Maize Conf., 11-15 February, $143-148$.

Xu JY, Crouch H (2008) Genomics of tropical maize, a stable food and feed across the world. Pp.333-370. In Genomics of Tropical Crop Plants, P. H. Moore and R. Ming (eds.). Springer, London, UK.

Yingzhong Z (1999) Combining ability analysis of agronomic characters in sesame. The Institute of Sustainable Agriculture (IAS), CSIC.

Zhang D, Kang MS, Lamkey KR (2005) Diallel-SAS05: A comprehensive program for Griffing's and Gardner-Eberhart analyses. Agron. J. 97: 1097-1106.

Zivanovic T, Secanski M, Filipovic M (2007) Combining abilities for the number of kernel rows per ear in silage maize. Plant breeding and seed production, XIII (3-4): 13-19. 